David Shambaugh and Gudrun Wacker, eds., American and European Relations with China: Advancing Common Agendas

Berlin, Stiftung Wissenschaft und Politik, June 2008, 144 pp.

Jean-Pierre Cabestan

CpenEdition

Journals

Electronic version

URL: http://journals.openedition.org/chinaperspectives/4821

DOI: 10.4000/chinaperspectives.4821

ISSN: 1996-4617

Publisher

Centre d'étude français sur la Chine contemporaine

Printed version

Date of publication: 1 June 2009

Number of pages: 121-122

ISSN: 2070-3449

Electronic reference

Jean-Pierre Cabestan, « David Shambaugh and Gudrun Wacker, eds., American and European

Relations with China: Advancing Common Agendas », China Perspectives [Online], 2009/2 | 2009,

Online since 01 June 2009, connection on 21 September 2020. URL : http://journals.openedition.org/ chinaperspectives/4821; DOI : https://doi.org/10.4000/chinaperspectives.4821

This text was automatically generated on 21 September 2020.

(c) All rights reserved 


\title{
David Shambaugh and Gudrun Wacker, eds., American and European Relations with China: Advancing Common Agendas
}

\author{
Berlin, Stiftung Wissenschaft und Politik, June 2008, 144 pp.
}

Jean-Pierre Cabestan

1 This slender, compact work sets out to assess the differences and convergences between the China policies of the United States and the European Union (EU). This large-sized volume (A4 paper) brings together papers given at a conference organised by the publishing institution in February 2008 and reflects the state of American and Europeans relations with China on the eve of the Beijing Olympics, the election of Barack Obama, and the world financial crisis. In this sense, this collection of short articles is to be understood in a particular historical frame. As the subtitle suggests, the book is designed more to influence the policies of the governments concerned than to provide one more contribution to the already abundant literature on China-US and China-EU relations.

2 That said, the chapters here presented, written by some of the leading experts on both sides of the Atlantic on China's foreign policy and security, are still relevant and full of insight concerning the uncertain period that we are now entering. They cast light on some of the well-known structural differences between the American and European approaches to China. Given its strategic role in the Asia-Pacific region, Washington cannot but see Beijing through a prism in which the contentious issues of Taiwan, the military modernisation of the People's Liberation Army, and the rise of China in the region counterbalance commercial and political issues such as human rights and good governance, indeed often pushing them into the background, and the temptation to contain the People's Republic remains a factor in North America.

Conversely, the EU sees China first and foremost as an economic and diplomatic partner whose internal development is to be encouraged, as is its integration into the 
international community. In other words, for a long time the EU demonstrated an inability to formulate a China policy that would take account of security questions. This was clearly demonstrated in 2003 by the willingness of France and Germany to lift the embargo on arms sales to China that had been adopted post-Tiananmen. The reasons put forward by Gerhard Schröder and Jacques Chirac at the time were the relative improvement in the country's human rights record, but in the process they forgot to take note of the change in the balance of forces in the Taiwan Strait and China's rapid military modernisation.

At the same time, however, discussions over the embargo that followed contributed to the questioning of this over-simplistic dichotomy between Europe and America. This brought about increased transatlantic tension and forced the United States to set up a direct dialogue with the EU over China, just as it obliged the European proponents of the lifting of the embargo to take into consideration the strategic impact of such a decision.

5 The conference that gave rise to this publication should be seen in the context of the exchange of views that American and European specialists on China have been engaging in ever since. It is not that these specialists did not see each other prior to that, but in many respects, when they thought about the relations between their respective countries and China, neither side considered the viewpoint and interests of the other as being paramount; and nor did the governments they advised or the political leaders who consulted them.

6 This work and the dialogue it represents bear a kind of witness to the rise in influence, if not in power, of the EU in Asia. It also demonstrates the importance, in international relations in the post- Cold War period, not only of economic and trade questions, but also of global problems such as climate change, sustainable development, and good governance.

7 The work also shows that the failure to lift the embargo in 2005 has contributed to an increase in the number of subjects on which both sides of the Atlantic are finding common ground with regard to China - for example, the increase in the sticking points in China-Europe trade due to the cutting of China's surplus; the growing irritation within European public opinion with China's slow progress on human rights in spite of the generous cooperation programmes put in place by the EU in this area, and the belated awareness of the fundamentally neo-realist character of inter-state relations in the Asia-Pacific region (and the rest of the world outside the EU).

Nonetheless, the United States and the EU cannot hope to develop exactly the same sort of relations with China, even following Obama's election. As several contributions point out, the EU is not a power in any real sense, and it has only an indirect and secondary influence on the strategic situation in the Asia-Pacific region. There is also the fact that within the EU itself positions and interests are far from consistently aligned, a weakness to which this work does not give adequate prominence. For example, whilst the possibility of one kind of trade competition among EU member states is common knowledge (particularly between France and Germany), another kind, related to the export of different legal systems (between continental European law and common law) is much less well known; and yet it is this sometimes quite sterile competition that acts as a brake to any coordinated action by the EU in the field of law and human rights. into the international community, its acceptance, complete or merely partial, of 
multilateralism, and its revisionist intentions divide Americans as much as Europeans. The message that emerges is that both parties need to adopt a policy of engagement with China without it being one of blind engagement, and that vigilance and EU-US dialogue remain as important as ever. One cannot but agree with such wisdom.

\section{AUTHOR}

\section{JEAN-PIERRE CABESTAN}

Professor of Political Sciences and Head of the Department of Governmental and International Studies, Baptist University, Hong Kong. 